\title{
NEW DISTRIBUTIONAL DATA ON BRYOPHYTES OF POLAND AND SLOVAKIA, 7
}

\author{
Piotr Górski, Michą Smoczyk, StanisŁaw Rosadziński, Monika Staniaszek-KiK, \\ Henryk Klama, PaweŁ Pawlikowski, Marcin Wilhelm, Katarzyna Topolska, Maciej Romański
}

\author{
Editors of the column: PIOTR GóRSKI, ANNA RusiŃSKA
}

Series "New distributional data on bryophytes of Poland (and Slovakia)" is a scientific bulletin of Bryological Section of Polish Botanical Society

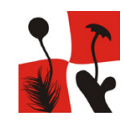

P. Górski, Department of Botany, Poznań University of Life Sciences, Wojska Polskiego 71 C, 60-625 Poznań, Poland, e-mail: peter@up.poznan.pl

H. Klama, Institute of Environmental Protection and Engineering, University of Bielsko-Biała, Willowa 2, 43-309 Bielsko-Biała, Poland, e-mail: hklama@ath.bielsko.pl

P. Pawlikowski, Department of Plant Ecology and Environmental Conservation, Institute of Botany, Faculty of Biology, Biological and Chemical Research Centre, University of Warsaw, Żwirki i Wigury 101, 02-096 Warsaw, Poland, e-mail: p.pawlikowski@uw.edu.pl

M. Romański, Wigry National Park, Krzywe 82, 16-402 Suwałki, Poland, e-mail: maciej.romanski@wigry. org.pl

S. Rosadziński, Department of Plant Ecology and Environmental Protection, Faculty of Biology, Adam Mickiewicz University, Umultowska 89, 61-614 Poznań, Poland, e-mail: stanros@gmail.com

A. Rusińska, Natural History Collections, Adam Mickiewicz University, Umultowska 89, 61-614 Poznań, Poland, e-mail: annarus@amu.edu.pl

M. Smoczyk, Wojska Polskiego 30/5, 69-110 Rzepin, Poland, e-mail: msmoczyk@wp.pl

M. Staniaszek-Kik, Department of Geobotany and Plant Ecology, University of Łódź, Banacha 12/16, 90237 Łódź, Poland, e-mail: kik@biol.uni.lodz.pl

K. Topolska, Department of Plant Ecology and Environmental Conservation, Institute of Botany, Faculty of Biology, Biological and Chemical Research Centre, University of Warsaw, Żwirki i Wigury 101, 02-096 Warsaw, Poland, e-mail: katarzyna.topolska7@gmail.com

M. Wilhelm, Department of Geobotany and Plant Taxonomy, Faculty of Biology, University of Szczecin, Wąska 13, 71-415 Szczecin, Poland, e-mail: junin@univ.szczecin.pl

(Received: May 18, 2016. Accepted: July 6, 2016)

\section{Amblystegium radicale (P. Beauv.) Schimp.}

Authors: M. STANIASZEK-KIK, S. RosADZiŃSKI

ATMOS De-22: Central Poland, Szczerców Basin (Kotlina Szczercowska), $1.9 \mathrm{~km}$ south-east of the village of Chrusty, $51.35942^{\circ} \mathrm{N}, 18.95528^{\circ} \mathrm{E}$, Carici elongatae-Alnetum, leg., det. S. Rosadziński, 25.06.2014
(POZG); ATMOS De-32: Central Poland, Szczerców Basin, Wielun Forest Inspectorate, $0.78 \mathrm{~km}$ southeast of the village of Beresie Duże, $51.48328^{\circ} \mathrm{N}$, $18.92901^{\circ} \mathrm{E}$, Molinia caerulea-Alnus glutinosa community, leg., det. S. Rosadziński, M. Staniaszek-Kik, 23.06.2014 (LOD); ATMOS De-32: Central Poland, Bełchatów Upland (Wysoczyzna Bełchatowska), Ra- 
domsko Forest Inspectorate, $0.62 \mathrm{~km}$ south-west of the village of Kurzyna, $51.16315^{\circ} \mathrm{N}, 19.02390^{\circ} \mathrm{E}$, Carici elongatae-Alnetum, leg., det. M. Staniaszek-Kik, S. Rosadziński, 24.06.2014 (POZG); ATMOS De-36: Central Poland, Bełchatów Upland, Bełchatów Forest Inspectorate, $0.4 \mathrm{~km}$ south-west of the village of Napolenów, $51.25279^{\circ} \mathrm{N}, 19.49965^{\circ} \mathrm{E}$, Caricetum acutiformis, leg. S. Rosadziński, M. Staniaszek-Kik, 24.06.2014, det. M. Staniaszek-Kik (LOD); ATMOS De-24: Central Poland, Bełchatów Upland, Bełchatów Forest Inspectorate, $2.6 \mathrm{~km}$ north-west of the village of Kluki, $51.34537^{\circ} \mathrm{N}, 19.19909^{\circ} \mathrm{E}, \mathrm{Ca}$ rici remotae-Fraxinetum, leg., det. S. Rosadziński, M. Staniaszek-Kik, 25.06.2014 (POZG); ATMOS De53: Central Poland, Włoszczowska Basin (Niecka Włoszczowska), Radomsko Forest Inspectorate, 0.6 $\mathrm{km}$ west of the village of Płaszczyzna, $51.05994^{\circ} \mathrm{N}$, $19.10183^{\circ} \mathrm{E}$, degenerated patches of Sphagno-Alnetum, leg., det. S. Rosadziński, M. Staniaszek-Kik, 25.06.2014 (LOD).

Amblystegium radicale has a boreal-temperate-type range (Düll \& MeINUnger 1989), but, according to some authors, it is an amfiatlantic species (RUSIŃSKA 1981). According to Dierssen (2001), A radicale is rare in the whole geographical range but is overlooked. In Poland, it is a vulnerable species (ŻARNOwIEC et al. 2004), and it is threatened in Europe (SCHUMACKER \& MARTINY 1995). This taxon is known mainly from the Bieszczady Zachodnie Range (Armata 2006, Stebel \& Koczur 2012), Upper Silesia (FojciK \& Stebel 2006), and Świętokrzyski National Park (Stebel et al. 2013), from the Wielkopolska region (GoŁDYN et al. 2007), and from just one locality from central Poland (WozIWODA \& STANIASZEK-KIK 2012).

\section{Campylopus introflexus (Hedw.) Brid.}

Authors: P. GóRSKI, M. WILHELM

ATMOS Cb-52: W Poland, NW Wielkopolska region, Gorzów Basin (Kotlina Gorzowska), Wielkopolskie Province, Czarnków-Trzcianka County, Drawsko commune, forest section 484a of the Potrzebowice Forest Inspectorate (Kwiejce Forestry), $52.77482^{\circ} \mathrm{N}$, 15.97697E, det. P. Górski, 28.06.2015; ATMOS Cb61 (W Poland, NW Wielkopolska region, Gorzów Basin, Lubuskie Province): Międzychód County, Skwierzyna commune, forest section 24la of the Międzychód Forest Inspectorate (Żmijowiec Forestry), $52.68708^{\circ} \mathrm{N}, 15.8035^{\circ} \mathrm{E}$, Corniculario-Cladonietum mitis, det. P. Górski, 14.06.2015; Międzychód County, Skwierzyna commune, forest section $247 \mathrm{~b}$ of the Międzychód Forest Inspectorate (Żmijowiec Forestry), $\quad 52.68211^{\circ} \mathrm{N}, \quad 15.76989^{\circ} \mathrm{E}, \quad$ sandy soil at the edge of a young pine plantation, det. M. Wilhelm, 26.06.2015; Strzelce-Drezdenko County, Drezdenko commune, forest section 567b of the Karwin Forest Inspectorate (Odyniec Forestry), $52.73933^{\circ} \mathrm{N}$, $15.88125^{\circ} \mathrm{E}$, det. P. Górski, 22.06.2015; Strzelce-
-Drezdenko County, Drezdenko commune, forest section $309 z$ of the Karwin Forest Inspectorate (Grotów Forestry), $52.75334^{\circ} \mathrm{N}, \quad 15.84842^{\circ} \mathrm{E}$, Leucobryo-Pinetum, det. M. Wilhelm, 22.06.2015; Strzelce-Drezdenko County, Drezdenko commune, forest section $316 \mathrm{f}$ of the Karwin Forest Inspectorate (Sosnówka Forestry), $52.75128^{\circ} \mathrm{N}, 15.80164^{\circ} \mathrm{E}$, Leucobryo-Pinetum, det. M. Wilhelm, 26.06.2015; Strzelce-Drezdenko County, Drezdenko commune, forest section $317 \mathrm{~g}$ of the Karwin Forest Inspectorate (Sosnówka Forestry), $52.75089^{\circ} \mathrm{N}, \quad 15.79781^{\circ} \mathrm{E}$, young pine plantation, det. M. Wilhelm, 26.06.2015; Strzelce-Drezdenko County, Drezdenko commune, forest section 586h of the Karwin Forest Inspectorate (Lubiatów Forestry), $52.72335^{\circ} \mathrm{N}, \quad 15.77759^{\circ} \mathrm{E}$, young pine plantation, det. M. Wilhelm, 11.06.2015; Strzelce-Drezdenko County, Drezdenko commune, forest section $663 \mathrm{c}$ of the Karwin Forest Inspectorate (Lubiatów Forestry), $52.73186^{\circ} \mathrm{N}, \quad 15.84364^{\circ} \mathrm{E}$, young pine plantation, det. M. Wilhelm, 26.06.2015; Strzelce-Drezdenko County, Drezdenko commune, forest section 747 $\mathrm{j}$ of the Karwin Forest Inspectorate (Lubiatów Forestry), $52.71847^{\circ} \mathrm{N}, \quad 15.83224^{\circ} \mathrm{E}$, young pine plantation, det. M. Wilhelm, 22.06.2015; Strzelce-Drezdenko County, Drezdenko commune, forest section $657 \mathrm{~d}$ of the Karwin Forest Inspectorate (Odyniec Forestry), $52.73364^{\circ} \mathrm{N}, 15.87721^{\circ} \mathrm{E}$, det. P. Górski, 22.06.2015; ATMOS Cb-61 (W Poland, NW Wielkopolska region, Gorzów Basin, Wielkopolskie Province): Międzychód County, Międzychód commune, forest section 351a of the Międzychód Forest Inspectorate (Mokrzec Forestry), $52.68543^{\circ} \mathrm{N}$, 15.86978 ${ }^{\circ}$ E, det. P. Górski, 14.06.2015; Międzychód County, Międzychód commune, forest section 165b of the Międzychód Forest Inspectorate (Sowia Góra Forestry), Pohlio-Callunetum, $52.70089^{\circ} \mathrm{N}$, $15.86749^{\circ} \mathrm{E}$, det. P. Górski, 14.06.2015; Międzychód County, Międzychód commune, forest section $230 \mathrm{f}$ of the Międzychód Forest Inspectorate (Sowia Góra Forestry), $52.69225^{\circ} \mathrm{N}, 15.85794^{\circ} \mathrm{E}$, Pohlio-Callunetum, det. P. Górski, 14.06.2015; ATMOS Cb-62 (W Poland, NW Wielkopolska region, Gorzów Basin, Lubuskie Province): Strzelce-Drezdenko County, Drezdenko commune, forest section 731a of the Karwin Forest Inspectorate (Odyniec Forestry), $52.73365^{\circ} \mathrm{N}, 15.91674^{\circ} \mathrm{E}$, Corniculario-Cladonietum mitis, det. P. Górski, 13.06.2015; Strzelce-Drezdenko County, Drezdenko commune, forest section 652b of the Karwin Forest Inspectorate (Odyniec Forestry), $52.74089^{\circ} \mathrm{N}, 15.89946^{\circ} \mathrm{E}$, det. P. Górski, 22.06.2015; Strzelce-Drezdenko County, Drezdenko commune, forest section 651a of the Karwin Forest Inspectorate (Odyniec Forestry), $52.7412^{\circ} \mathrm{N}, 15.90839^{\circ} \mathrm{E}$, det. P. Górski, 22.06.2015; Strzelce-Drezdenko County, Drezdenko commune, forest section $648 \mathrm{c}$ of the Karwin Forest Inspectorate (Odyniec Forestry), $52.73861^{\circ} \mathrm{N}, 15.92382^{\circ} \mathrm{E}$, det. P. Górski, 25.06.2015; Strzelce-Drezdenko County, Drezdenko commune, 
forest section 474b of the Karwin Forest Inspectorate (Grotów Forestry), $52.74802^{\circ} \mathrm{N}, 15.89669^{\circ} \mathrm{E}$, det. P. Górski, 22.06.2015; ATMOS Cb-62 (W Poland, NW Wielkopolska region, Gorzów Basin, Wielkopolskie Province): Międzychód County, Międzychód commune, forest section 406i of the Międzychód Forest Inspectorate (Kamień Forestry), $52.67947^{\circ} \mathrm{N}$, $15.90294^{\circ} \mathrm{E}$, secondary forest communities with contribution of Picea abies, det. M. Wilhelm, 26.06.2015; Międzychód County, Międzychód commune, forest section 216b of the Międzychód Forest Inspectorate (Sowia Góra Forestry), $52.70586^{\circ} \mathrm{N}, 15.93222^{\circ} \mathrm{E}$, Pohlio-Callunetum, det. P. Górski, 12.06.2015; Międzychód County, Międzychód commune, forest section 155d of the Międzychód Forest Inspectorate (Sowia Góra Forestry), $52.71124^{\circ} \mathrm{N}, 15.92311^{\circ} \mathrm{E}$, Pohlio-Callunetum, det. P. Górski, 13.06.2015; Międzychód County, Sieraków commune, forest section 96b of the Sieraków Forest Inspectorate (Czapliniec Forestry), $52.70734^{\circ} \mathrm{N}, 159552^{\circ} \mathrm{E}$, det. P. Górski, 13.06.2015; Międzychód County, Sieraków commune, forest section 72a of the Sieraków Forest Inspectorate (Gospódka Forestry), $52.71608^{\circ} \mathrm{N}, 15.9564^{\circ} \mathrm{E}$, Pohlio-Callunetum, det. P. Górski, 13.06.2015; Międzychód County, Sieraków commune, forest section 16a of the Sieraków Forest Inspectorate (Gospódka Forestry), $52.74183^{\circ} \mathrm{N}, 15.95244^{\circ} \mathrm{E}$, det. P. Górski, 28.06.2015; Czarnków-Trzcianka County, Drawsko commune, forest section $612 \mathrm{a}$ of the Potrzebowice Forest Inspectorate (Przecznik Forestry), $52.74971^{\circ} \mathrm{N}$, $15.9872^{\circ} \mathrm{E}$, det. P. Górski, 28.06.2015; Czarnków-Trzcianka County, Drawsko commune, forest section $611 \mathrm{j}$ of the Potrzebowice Forest Inspectorate (Przecznik Forestry), $52.75553^{\circ} \mathrm{N}, 15.98496^{\circ} \mathrm{E}$, det. P. Górski, 28.06.2015; ATMOS Cb-71: W Poland, NW Wielkopolska region, Gorzów Basin, Lubuskie Province, Międzychód County, Skwierzyna commune, forest section 368h of the Międzychód Forest Inspectorate (Żmijowiec Forestry), $52.66275^{\circ} \mathrm{N}$, $15.78206^{\circ} \mathrm{E}$, young pine plantation, det. M. Wilhelm, 26.06.2015; ATMOS Cb-71 (W Poland, NW Wielkopolska region, Gorzów Basin, Wielkopolskie Province): Międzychód County, Międzychód commune, forest section 427a of the Międzychód Forest Inspectorate (Żmijowiec Forestry), $52.66611^{\circ} \mathrm{N}$, $15.80185^{\circ} \mathrm{E}$,sandy soil at the edge of a young pine plantation, det. P. Górski, 14.06.2015; Międzychód County, Międzychód commune, forest section 572h of the Międzychód Forest Inspectorate (Przedlesie Forestry), $52.6432^{\circ} \mathrm{N}, \quad 15.80696^{\circ} \mathrm{E}$, det. P. Górski, 15.06.2015; Międzychód County, Międzychód commune, forest section 590f of the Międzychód Forest Inspectorate (Przedlesie Forestry), $52.64434^{\circ} \mathrm{N}$, $15.85061^{\circ} \mathrm{E}$, det. P. Górski, 24.06.2015; Międzychód County, Międzychód commune, forest section $531 \mathrm{k}$ of the Międzychód Forest Inspectorate (Przedlesie Forestry), $52.65607^{\circ} \mathrm{N}, 15.85136^{\circ} \mathrm{E}$, det. P. Górski, 24.06.2015; Międzychód County, Międzychód com- mune, forest section 588i of the Międzychód Forest Inspectorate (Przedlesie Forestry), $52.64583^{\circ} \mathrm{N}$, 15.86131 ${ }^{\circ}$ E, det. P. Górski, 24.06.2015; Międzychód County, Międzychód commune, forest section 537k of the Międzychód Forest Inspectorate (Przedlesie Forestry), $52.65024^{\circ} \mathrm{N}, 15.81688^{\circ} \mathrm{E}$, sandy soil at the edge of a young pine plantation, det. P. Górski, 15.06.2015; Międzychód County, Międzychód commune, forest section 56b of the Międzychód Forest Inspectorate (Muchocin Forestry), $52.6196^{\circ} \mathrm{N}$, 15.80655 ${ }^{\circ}$, det. P. Górski, 24.06.2015; ATMOS Cb72 (W Poland, NW Wielkopolska region, Gorzów Basin, Wielkopolskie Province): Międzychód County, Sieraków commune, forest section 256 c of the Sieraków Forest Inspectorate (Czapliniec Forestry), $52.66828^{\circ} \mathrm{N}, 15.99251^{\circ} \mathrm{E}$, young pine plantation, det. M. Wilhelm, 11.06.2015; Międzychód County, Międzychód commune, forest section 551c of the Międzychód Forest Inspectorate (Kamień Forestry), $52.66656^{\circ} \mathrm{N}, 15.92606^{\circ} \mathrm{E}$, Leucobryo-Pinetum, det. M. Wilhelm, 26.06.2015; Międzychód County, Międzychód commune, forest section 549d of the Międzychód Forest Inspectorate Kamień, $52.66784^{\circ} \mathrm{N}$, $15.93756^{\circ} \mathrm{E}$,sandy soil at the edge of a young pine plantation, det. P. Górski, 12.06.2015; Międzychód County, Międzychód commune, forest section 553a of the Międzychód Forest Inspectorate (Kamień Forestry), $52.66604^{\circ} \mathrm{N}, \quad 15.91559^{\circ} \mathrm{E}$, sandy soil at the edge of a young pine plantation, det. P. Górski, 13.06.2015.

The above compiled localities of Campylopus introflexus are localised in one of the biggest complexes of coniferous forests in Poland - Puszcza Notecka Forest. The study covered 26000 ha $\left(260 \mathrm{~km}^{2}\right)$, almost $20 \%$ of the Puszcza Notecka Forest, in the eastern portion. Altogether, 39 localities of $C$. introflexus were catalogued. Currently, this neophytic moss is common in Puszcza Notecka Forest. It is worth noting that even in the 1990s, the species has been recorded sporadically (W. Rakowski, unpublished data). It has been not noted during phytosociological studies concerning moorlands of the Wielkopolska region that covered the entire area of Puszcza Notecka Forest (RAKOWSKi 2001, 2003, 2009). The present state of distribution of $C$. introflexus in the area is caused by its expansion in the last ca 10 years.

\section{Campylopus pyriformis (Schultz) Brid.}

Authors: S. RosadzińsKi, M. STANIASZEK-KIK

ATMOS Ed-24: Central Poland, Szczerców Basin, Bełchatów Forest Inspectorate, near the village of Trząs in the Kluki commune, on muck soil on the edge of a peat-water body, $51.29197^{\circ} \mathrm{N}, 19.21454^{\circ} \mathrm{E}$, leg., det. S. Rosadziński, M. Staniaszek-Kik, 23.06.2014 (LOD); ATMOS Ed-35: Central Poland, Bełchatów Upland, Bełchatów Forest Inspectorate, near the village of Huby Ruszczyńskie, on degraded transi- 
tional mire, in the small and overdried patches of a Ranunculo-Juncetum bulbosi community on muck soil, $51.23652^{\circ} \mathrm{N}, 19.42722^{\circ} \mathrm{E}$, leg., det. S. Rosadziński, M. Staniaszek-Kik, 23.06.2014 (LOD).

Campylopus pyriformis grows on sandy soil or bare peat in woodlands, on wet heaths, and in peat cuttings as well as on decaying stumps, logs, and Molinia caerulea tussocks (Dierssen 2001). Its presence in peatlands may be evidence of advanced degenerative processes caused by drying and eutrophication (Hübschmann 1986, Drehwald \& Preising 1991, MarSTALLER 2006). Some authors have suggested that this species may have been introduced to Europe during historical times (ArTs \& Frahm 1990, Stebel 2013). In Poland, it is known mainly in the north-western and south-western parts of the country (RUSiŃsKA 1981, RosadZiŃSKi 2013, WiLHELm 2015). Until now, this species had not been recorded in central Poland (STANIASZEK-KiK \& WolsKi 2009).

\section{Cephaloziella elachista (J.B. Jack ex Gottsche et Rabenh.) Schiffn.}

Author: M. SMOczYK

ATMOS Fb-34: SW Poland, Central Sudety Mountains (Sudety Środkowe), Bystrzyckie Mountains (Góry Bystrzyckie), ‘Torfowisko pod Zieleńcem' nature reserve, forest section $229 \mathrm{~d}$ of the Zdroje Forest Inspectorate, $50.3452^{\circ} \mathrm{N}, 16.4189^{\circ} \mathrm{E}$, alt. $750 \mathrm{~m}$ above sea level (a.s.l.), transitional peatbog, on a Polytrichum strictum hummock growing with Calypogeia sphagnicola and Fuscocephaloziopsis (=Cephalozia) connivens, leg. M. Smoczyk, 29.05.2015, det. P. Górski, c. per. (POZG).

Scattered localities of Cephaloziella elachista are known from central and northern Poland (SzWEYKOWsKI 2006). Recently, more localities were found in western and north-western Poland (GóRSKI 2013, GóRSKI \& GĄBKA 2015, GóRSKI et al. 2015). It seems to be a rare, poor fen species. Cephaloziella elachista has been collected here for the first time both in the 'Torfowisko pod Zieleńcem' nature reserve (Rerter 1920) as well in the Bystrzyckie Mts (KoŁA 1967).

\section{Frullania dilatata (L.) Dumort.}

Author: H. KLAmA

ATMOS Fd-92: S Poland, Western Carpathian Mountains (Karpaty Zachodnie), Silesian Foothills (Pogórze Śląskie), Silesian Province, Bielsko County, Jaworze, Zdrojowy Park (Park Zdrojowy), $49.79277^{\circ} \mathrm{N}, 18.95194^{\circ} \mathrm{E}$, alt. $402 \mathrm{~m}$ a.s.l., on trunks of Acer pseudoplatanus, Quercus robur, and Fraxinus excelsior, leg., det. H. Klama, 20.08.2015, c. per., c. spor. (herb. H. Klama).

Frullania dilatata is a widespread liverwort in Poland, occurring in the whole country. In the mountains, it grows in the lower forest zone. The species occurs on bark of deciduous trees and rarely on rocks. In the Silesian Foothills, it is quite frequent (f.e. RejMENT 1936, Klama \& ŻarNowieC 2011).

\section{Kurzia pauciflora (Dicks.) Grolle}

Authors: P. GóRSKI, M. ROMAŃSKI

ATMOS Af-85: NE Poland, Litewskie Lakeland (Pojezierze Litewskie), Puszcza Romincka Forest (Puszcza Romincka), 'Mechacz Wielki' nature reserve, $54.33053^{\circ} \mathrm{N}, 22.43883^{\circ} \mathrm{E}, 54.32944^{\circ} \mathrm{N}, 22.44516^{\circ} \mathrm{E}$, on peat, poor fen, growing with Mylia anomala, leg., det. P. Górski, M. Romański, 15.10.2015 (POZNB).

Kurzia pauciflora is a widespread liverwort in northern Poland (Szweykowski 2006). Many of its localities have been recognised in West Pomerania (SzWEYKOWSKI 1958 and the references cited therein; SZWEYKOWSKi \& KoźLICKA 1966, 1969, GórsKi 2013, GóRSKI \& KAPUSTYŃSKI 2015). Kurzia pauciflora was previously reported from a peat-bog and called 'Mechacz Wielki' by KopPe \& KopPe (1931).

\section{Orthocaulis binsteadii (Kaal.) H. Buch}

Author: P. GóRskI

ATMOS Gd-68: S Poland, Western Tatra Mountains (Tatry Zachodnie), MGRS 34UDV1351, below Mt Kończysty Wierch, NNW slope, alt. 1880 m a.s.l., Polytrichum-Sphagnum hummock, leg., det. P. Górski, 11.08.2004 (POZNB 2014, PRC).

Orthocaulis binsteadii is a subarctic-alpine species. In Europe, it grows in the mountains of the northern part of the continent (Norway, Sweden, Finland, Estonia, and Northern Russia). Moreover, it has been recorded in Svalbard, subarctic America, Canada, Siberia, Novaya Zemlya, and the Russian Far East (SÖDERSTRÖM et al. 2002). In the mountain ranges of central Europe, it occurs only in the Tatra Mountains, where it was first recorded in Poland by SzwEYKowsKi (1960a, b). Currently, O. binsteadii can be found in 10 localities in the Polish part of the Western and High Tatra Mountains (SzweYKowski 1960a, b, СүкоwsKA 2011, GóRsKi \& VÁŇA 2014), and in two localities in the Slovakian part of this massive (GóRSKI in ELLIS et al. 2012, GóRSKI \& VÁŇA 2014). In the Tatra Mountains $O$. binsteadii has been noted within altitude range of 1650 and $1920 \mathrm{~m}$ a.s.l. In the presented locality, $O$. binsteadii grows profusely in its typical habitat in the Tatra Mountains, as a component of a Polytrichum-Sphagnum hummock on a slope with a northern exposure.

\section{Orthodontium lineare Schwägr.}

Author: P. GóRSKI

ATMOS Ac-37: N Poland, East Pomerania (Pomorze Wschodnie), Pomerania Province, Puck County, ca $1 \mathrm{~km}$ north-east of the village of Odargowo, 'Zie- 
lone' nature reserve, leg., det. P. Górski, 22.04.2013 (POZNB); ATMOS Bb-14: NW Poland, West Pomerania (Pomorze Zachodnie), Koszalin Coastland (Pobrzeże Koszalińskie), Białogard Plain (Równina Białogardzka), West Pomerania Province, Koszalin County, Świeszyno commune, $54.07420^{\circ} \mathrm{N}$, $16.20630^{\circ} \mathrm{E}$, ca $2.8 \mathrm{~km}$ east of the village of Niedalino, ca $600 \mathrm{~m}$ north from W shore of Jezioro Hajka lake, forest section 193 of Manowo Forest Inspectorate, Vaccinio uliginosi-Pinetum association, leg., det. P. Górski, 2.05.2015 (POZNB).

Orthodontium lineare is a neophytic moss among the bryoflora of Poland (Ochyra 1982). In Poland, it is known mainly from the north-western part of the country (UrbańsKi 1987, FudALI 1993, Gos \& Gos 1993, RusińSKA \& URBAŃSKi 1993, FudALI et al. 2009). Recently, this moss was reported from southern Poland (ҒојсIK 2015).

\section{Orthotrichum cupulatum Hoffm. ex Brid.}

Author: M. SMOcZYK

ATMOS Da-14: W Poland, Lubuskie Lakeland (Pojezierze Lubuskie), Torzym Plain (Równina Torzymska), $1.9 \mathrm{~km}$ north-west of the church in Radzików, forest section $89 \mathrm{~g}$ of the Cybinka Forest Inspectorate, $52.2778^{\circ} \mathrm{N}, 14.8428^{\circ} \mathrm{E}$, one tuft on concrete forest section pillar by the forest road, growing with Orthotrichum anomalum, O. diaphanum, Dryptodon pulvinatus, and Syntrichia ruralis in a patch of Orthotricho anomali-Grimmietum pulvinatae association, leg., det. M. Smoczyk, 1.05.2015, teste V. Plášek, c. spor. (POZG). Orthotrichum cupulatum is an epilithic moss, mostly growing on limestone rocks and rarely on walls and other anthropogenic stone habitats (SCHÄFER-VERWIMP 2001, PLÁšEK 2012). The species is rare in the Lubuskie Lakeland and has been collected only two times in the nineteenth century near the village of Trzemeszno Lubuskie (ReINHARDT 1863) and near Niesłysz Lake (WARnstorf 1885, Torka 1904). The nearest known locality of $O$. cupulatum is situated in the vicinity of the city of Frankfurt/O in Germany (Meinunger \& Schröder 2007). The specimen found belongs to the typical variety (var. cupulatum).

\section{Porella platyphylla (L.) Pfeiff.}

Author: H. KLAMA

ATMOS Fd-92: S Poland, Western Carpathians, Silesian Foothills, Silesian Province, Bielsko County, Jaworze, Zdrojowy Park, $49.7925^{\circ} \mathrm{N}, 18.95388^{\circ} \mathrm{E}$, alt. 390 m a.s.l., on trunks of Acer pseudoplatanus, Quercus robur, and Fraxinus excelsior, leg., det. H. Klama, 20.08.2015, ster. (herb. H. Klama).

Porella platyphylla is a rare liverwort endangered of extinction in Poland (category E, KLAMA 2006). It is an epiphytic species, also growing on rocks. The plant occurs in the lowlands and in the lower for- est zone; at present, it is frequent in calcareous areas only. In the 1930s, the species was very common in the Cieszyn Foothills (Pogórze Cieszyńskie, western part of the Silesian Foothills) and in the Beskid Śląski Mountains (Rejment 1936, Rejment-GrochowSKA 1950). Currently, it is rare, in the Western Carpathians growing in single stations only (MIERZEŃSKA 1994, Klama 1996, 2013, Stebel \& Wilczek 2000, Plášek \& Stebel 2002, Nejfeld \& Stebel 2007, Ochyra \& CYKowsKa 2008, Górski \& VÁŇa 2014).

\section{Porella platyphylla (L.) Pfeiff.}

\section{Authors: P. PAwLIKOWSKI, K. TOPOLSKA}

ATMOS Bf-40: NE Poland, Masurian Lake District (Pojezierze Mazurskie), Warmia-Masuria Province, Mrągowo County, Mikołajki commune, Masurian Landscape Park, settlement of Urwitałt by Łuknajno Lake, $53.80593^{\circ} \mathrm{N}, 21.64153^{\circ} \mathrm{E}$, neglected, old park with broadleaf tree stand, extensive carpet on a moderately shaded bark of an old Fraxinus excelsior growing by the former pond along with other epiphytes, such as Homalothecium sericeum, Leucodon sciuroides, and Radula complanata, leg. P. Pawlikowski, K. Topolska, 26.07.2015, det. P. Pawlikowski (WA 52233).

Porella platyphylla is considered threatened with extinction in Poland (category E, KLAMA 2006). The species is known to occur in scattered localities throughout the country, on bark of deciduous trees, and on rocks (SzWEYKOWSKi 1958). Porella platyphylla used to be very rare in the Masurian Lake District; no localities have been published from the region for $c a$ 80 years (Koppe \& Koppe 1937), but there are some recent, unpublished records of the species from Olsztyn Lakeland and the Masurian Plain mesoregions, both within the Masurian Lake District (M. Szczepański, unpublished). Aside from this, during recent decades $P$. platyphylla almost has exclusively been recorded on limestone rocks in the Małopolska Upland (Janicka 2012, Piwowarski \& Paciorek 2012) and on tree bark in well-preserved forest complexes in West Pomerania (RUsińsKA et al. 2010, GóRSKI 2013) as well as in the Białowieża Forest (Stebel et al. 2003), the Carpathians (Klama 1996, Zubel 2002, GóRSKi \& VÁŇA 2014), and the Sudety Mts (BerdowsKi 2004). Localities outside large forest areas (e.g., in the 'Dębowiec' nature reserve in the Przedbórz Upland (KLAma et al. 2005) are extremely rare.

\section{Porella platyphylla (L.) Pfeiff.}

Author: M. SMOcZYK

ATMOS Fb-13: SW Poland, Central Sudety Mts, Stołowe Mountains (Góry Stołowe), Kudowa-Zdrój commune, south-eastern slope of Mount Parkowa Góra, $50.4450^{\circ} \mathrm{N}, 16.248^{\circ} \mathrm{E}$, alt. $480 \mathrm{~m}$ a.s.l., slits in slate outcrop within a mixed forest, leg., det. M. Smoczyk, 10.10.2012 (POZG); ATMOS Fb-14: Cen- 
tral Sudety Mts, Stołowe Mts, $1.7 \mathrm{~km}$ west of the church in the city of Radków, south-western slopes of Mount Guzowata, forest section 26f of the Zdroje Forest Inspectorate, $50.5026^{\circ} \mathrm{N}, 16.3763^{\circ} \mathrm{E}$, alt. 475 $\mathrm{m}$ a.s.l., sandstone and pudding-stone outcrops in mesic beech forest, leg., det. M. Smoczyk, 11.07.2012 (POZG); ATMOS Fb-24: SW Poland, Central Sudety Mts, Bystrzyckie Mts, Szczytna commune, Bystrzyca Dusznicka riverbank, $2.6 \mathrm{~km}$ south-west of the church in Szczytna, $50.4080^{\circ} \mathrm{N}, 16.4115^{\circ} \mathrm{E}$, alt. $500 \mathrm{~m}$ a.s.l., on sandstone block by riverbank and on trunk base of nearby sycamore maple, in patches of a Carici remotae-Fraxinetum association, growing with Homalia trichomanoides and Metzgeria furcata, leg., det. M. Smoczyk, 12.02.2014 (POZG); ATMOS Fb25: SW Poland, Central Sudety Mts, Kłodzko Basin, Kłodzko commune, $1.3 \mathrm{~km}$ south-east of the church in the village of Szalejów Górny, top of the cliff on the right bank of the Bystrzyca Dusznicka River, forest section $105 \mathrm{c}$ of the Zdroje Forest Inspectorate, $50.4220^{\circ} \mathrm{N}, 16.5612^{\circ} \mathrm{E}$, alt. $350 \mathrm{~m}$ a.s.l., trunk base of Corylus avellana, in oak-hornbeam forest from a Galio sylvatici-Carpinetum betuli association, accompanying species were Homalia trichomanoides and Plagiochila asplenioides, leg., det. M. Smoczyk, 1.05.2014 (POZG); ATMOS Fb-26: SW Poland, Central Sudety Mts, Kłodzko Basin, Kłodzko commune, $1.4 \mathrm{~km}$ northwest of the church in the village of Krosnowice, eastern slope of Mount Czerwoniak, forest section $311 \mathrm{~b}$ of the Bystrzyca Kłodzka Forest Inspectorate, $50.4038^{\circ} \mathrm{N}, 16.6307^{\circ} \mathrm{E}$, alt. $320 \mathrm{~m}$ a.s.l., sandstone outcrop by the road in oak-hornbeam forest from a Galio sylvatici-Carpinetum betuli association, leg., det. M. Smoczyk, 12.04.2014 (POZG); old limestone quarry on northern slope of Mt Czerwoniak within oak-hornbeam forest, forest section 311a of the Bystrzyca Kłodzka Forest Inspectorate, $50.4050^{\circ} \mathrm{N}$, $16.6308^{\circ} \mathrm{E}, 350 \mathrm{~m}$ a.s.l., not. M. Smoczyk, 7.06.2014; Eastern Sudety Mts, Śnieżnik Massif, Krowiarki, south-western slope of Mount Dębowa, forest section 304g of the Bystrzyca Kłodzka Forest Inspectorate, $50.3655^{\circ} \mathrm{N}, 16.6464^{\circ} \mathrm{E}$, alt. $430 \mathrm{~m}$ a.s.l., Kapelusz rock outcrop, slate rocks shaded by thickets, leg., det. M. Smoczyk, 23.07.2013 (POZG).

The stations of Porella platyphylla are known from almost the whole country, both in the mountains and lowland parts. However, the species is retreating (it is sensitive to air pollution and intensive forest management), and it has become a rare plant (SZWEYKOWSKI 2006), endangered with extinction (category E, KLAMA 2006). It grows mainly on bark of deciduous trees and on limestone rocks. In Kłodzko County, it was given from a single locality on Mount Krucza Kopa in the Stołowe Mts (SzweyKowski 1953) and from Mt Dębowa in the Śnieżnik Massif (BrowICZ \& SZWEYKOWSKI 1958) - the last locality is confirmed here.
11. Schljakovia kunzeana (Huebener) Konst. et Vilnet [=Barbilophozia kunzeana (Huebener) Müll. Frib.]

\section{Author: P. GóRSKI}

Slovakia, Western Tatra Mountains (Tatry ZachodNIE): MGRS 34UDV0747, below Mt Baranec, Polytrichum-Sphagnum hummock on ridge descending to west from the mount, $49.17557^{\circ} \mathrm{N}, 19.73101^{\circ} \mathrm{E}$, leg., det. P. Górski, 17.09.2015 (POZNB 2013); 34UDV0846, NW slope of Mt Malý Baranec, Polytrichum-Sphagnum hummock, $49.16782^{\circ} \mathrm{N}, 19.75063^{\circ} \mathrm{E}$, alt. $2035 \mathrm{~m}$ a.s.l., leg., det. P. Górski, 17.09.2015 (POZNB 2004); 34UDV1247, Otrhance ridge, below Mt Nižná Magura, rocky outcrops with north exposition, Polytrichum-Sphagnum hummock, $49.17201^{\circ} \mathrm{N}, 19.79502^{\circ} \mathrm{E}$, alt. $1840 \mathrm{~m}$ a.s.l., leg., det. P. Górski, 18.09.2015 (POZNB 2009); 34UDV2449, Liptovské kopy, S and above Turkovo sedlo pass, Polytrichum-Sphagnum hummock, together with Orthocaulis attenuatus, $49.20162^{\circ} \mathrm{N}, 19.973^{\circ} \mathrm{E}$, alt. $2025 \mathrm{~m}$ a.s.l., leg., det. P. Górski, 5.08.2015 (POZNB 2005, 2007), Liptovské kopy, Turkovo sedlo pass, Polytrichum-Sphagnum hummock, $49.19552^{\circ} \mathrm{N}, 19.96882^{\circ} \mathrm{E}$, alt. $1950 \mathrm{~m}$ a.s.l., leg., det. P. Górski, 5.08.2015 (POZNB 2006); 34UDV2550, Liptovské kopy, NE slope of Mt Vel'ká kopa, Polytrichum-Sphagnum hummock, $49.20138^{\circ} \mathrm{N}$, $19.97708^{\circ} \mathrm{E}$, alt. $1950 \mathrm{~m}$ a.s.l., leg., det. P. Górski, 4.08.2015 (POZNB 2008); Liptovské kopy, W slope of Mt Velká kopa, Polytrichum-Sphagnum hummock, $49.20162^{\circ} \mathrm{N}, 19.973^{\circ} \mathrm{E}$, alt. $2005 \mathrm{~m}$ a.s.l., leg., det. P. Górski, 5.08.2015 (POZNB 2003); Liptovské kopy, Vyšné Garajovo sedlo pass, Polytrichum-Sphagnum hummock, $49.20164^{\circ} \mathrm{N}, 19.97928^{\circ} \mathrm{E}$, alt. $1920 \mathrm{~m}$ a.s.l., leg., det. P. Górski, 4.08.2015 (POZNB 2010).

PolAND: ATMOS Ge-50, High Tatra Mountains (Tatry Wysokie), 34UDV2958, Toporowy Staw Wyżni lake, peat-bog, $49.27834^{\circ} \mathrm{N}, 20.02927^{\circ} \mathrm{E}$, alt. $1125 \mathrm{~m}$ a.s.l., leg., det. P. Górski, 3.08.2015 (POZNB 2011).

Schljakovia kunzeana is known in Poland from West Pomerania as well as the Sudety Mts and Carpathians (SZWEYKOWSKi 2006). Currently, the majority of its localities (85) are in the Tatra Mountains (GórsKI \& VÁŇA 2014). It is worth noting that during the 1950s, this species was considered very rare in the Tatra Mts, having three records only (SzWEYKOWSKI 1956). The increase in the number of S. kunzeana localities in this area is related to intensification of floristic studies (СүкоWsKa 2008, 2011, GóRsKi \& VÁŇA 2014). At present, this liverwort is not endangered in the Tatra Mts. It grows mostly in the alpine belt. As much as $69 \%$ of all known localities are located above $1800 \mathrm{~m}$ a.s.1. (92\% are located above $1700 \mathrm{~m}$ a.s.l.). It is most frequently found in Polytrichum-Sphagnum hummocks (SZWEYKOWSKI \& BucZKOWSKA 2000).

This report presents another 10 localities of this plant in four areas of the Tatra Mts. The first one is the ridge of Liptovské kopy and the surroundings of 
the highest peak of the ridge - Mount Vel'ká kopa. Of note, this is the area where the plant formation referred to as the Polytrichum-Sphagnum hummock was described for the first time (ЈеNí 1958). This work, however, lacks data on liverworts. The tufts on the slopes below Mt Velká kopa are formed mostly by lichens. The inclusion of bryophytes (including liverworts) is sparse. Floristically richer Polytrichum-Sphagnum hummocks can be found on the ridge north of Mt Velká kopa. In 2014, the second Slovakian locality of the arctic-alpine species Orthocaulis binsteadii (Kaal.) H. Buch was found there (leg. P. Górski, GóRSKI \& VÁŇA 2014). Other localities of S. kunzeana originate from the ridges of Othargance and Baranec. They are localised in the Western Tatra Mts, where only seven localities of the plant are known (KRUPA 1888, Duda \& VÁÑa 1990, GóRSKI \& VÁÑa 2014). The presented new locality of $S$. kunzeana from Poland comes from Toporowy Staw Wyżni Lake. It is a peat bog already known from the presence of many liverworts that are rare in the Tatra Mts (e.g., Odontoschisma fluitans and Fuscocephaloziopsis loitlesbergeri) and studied since 1912 (LiLIENFeldówna 1914). Both abovementioned species are still present there, more than a hundred years after their first observation by F. Lilienfeldówna (GórSKI 2014, 2015, GóRSKI \& VÁŇA 2014). It is worth emphasising that the locality of S. kunzeana in Toporowy Staw Wyżni Lake is one of the lowest in the Tatra Mts. The species has been recorded in a lower situated locality only in the Polana Molkówka glade (LiLIENFELDównA 1914).

\section{Scorpidium scorpioides (Hedw.) Limpr.}

\section{Authors: S. RosadziŃSKI, M. STANIASZEK-KIK}

ATMOS Ed-02: Central Poland, Szczerców Basin, 'Międzyrzecze Warty i Widawki' Landscape Park (Park Krajobrazowy Międzyrzecza Warty i Widawki), 'Korzeń' nature reserve, in Utriculario-Scorpidietum scorpioidis and Scorpidio-Caricetum diandrae associations, $51.48206^{\circ} \mathrm{N}, 18.88703^{\circ} \mathrm{E}$, leg., det. S. Rosadziński, 25.06.2014 (POZG).

Scorpidium scorpioides is a rare glacial relict in the moss flora. It prefers extremely wet habitats of shallow water reservoirs, especially with lime gyttja deposits. It most often appears on rich calcareous fens (Ochyra et al. 1988). Scorpidium scorpioides in Poland is known to occur in scattered localities mainly in the northern and north-western parts of the country (Ochyra et al. 1988). So far in central Poland, the species has been recorded only in a few localities: 1 . Bolimowski Landscape Park (Pisarek 1989, SAnderSKA et al. 2003); 2. Uroczysko Kuźnica Wielgie forest (KuCHARSKi \& KurZaC 1998); 3. Wielopole, near the city of Bełachtów (PlackowsKi 1984); 4. near the village of Kamień in the Szczerców commune (MAMIŃsKI 1986); and 5. near the villages of Chotów in the Krasocin commune (leg., det. W. Pisarek, 23.07.1990,
LOD), 6. Oleszno in the Krasocin commune (leg., det. W. Pisarek, 2.08.1990, LOD), 7. Dobrenice in the Łęki Szlacheckie commune (leg., det. W. Pisarek, 7.08.1990, LOD), and 8. Kolonia Kruszyna in the Wielgomłyny commune (leg., det. W. Pisarek, 8.01.1992, LOD). Most of these localities were reported more than 25 years ago, and it is difficult to assess whether they still exist.

\section{Trichocolea tomentella (Ehrh.) Dumort.}

Author: M. SMOcZYK

ATMOS Fb-45: SW Poland, Central Sudety Mts, Bystrzyckie Mts, $1 \mathrm{~km}$ south-east of the church in the village of Poręba, small stream valley on eastern slope of the Mount Dębosz, forest section 265c of the Bystrzyca Kłodzka Forest Inspectorate, $50.2232^{\circ} \mathrm{N}$, $16.5936^{\circ} \mathrm{E}$, alt. $580 \mathrm{~m}$ a.s.l., dense patch on humic soil by small stream in a Carici remotae-Fraxinetum association, leg., det. M. Smoczyk, 11.07.2015 (POZG). Trichocolea tomentella is a rare liverwort in the Sudety Mts (SzweYKowski 1966, 2006). In the Bystrzyckie mountain range, this species was given only once by KoŁa (1967), from the Bystrzyca Dusznicka River valley - a border area adjacent to the Orlickie Mountains. Old, general data from the vicinity of the town of Duszniki-Zdrój (Limpricht 1876) also exist. From the nearby Czech side of those mountain ranges, only a single locality of $T$. tomentella is known from the Orlickie Mts (PLÁšEK et al. 2012).

\section{ACKNOWLEDGEMENTS}

The contribution by P. Górski was funded by Department of Botany, University of Life Sciences in Poznań.

\section{REFERENCES}

ARmata L. (2006): New records of rare and endangered mosses from the Bieszczady Zachodnie Range and the Carpathian Foothills. Annales Universitatis Mariae Curie-Skłodowska, Sectio C, Biologia 61: 131-139.

ARTS T., Frahm J.-P. (1990): Campylopus pyriformis new to North America. Bryologist 93 (3): 290-294.

BERDOWSKI W. (2004): Brioflora rezerwatu „Wodospad Wilczki" w województwie dolnośląskim. Acta Botanica Silesiaca 1: 167-175.

Browicz K., Szweykowski J. (1958): Nowe stanowiska Grimaldia fragrans (Balbis) Corda, Fimbriaria saccata (Wahl.) Nees oraz Riccia ciliifera Link ( $R$. bischoffii Hüb.) w Polsce południowej. Fragmenta Floristica et Geobotanica 4(1-2): 203-219.

Сүкошsка В. (2008): A contribution to the bryoflora of the subnival belt in the Polish Tatra Mountains. In: A. Stebel, R. Ochyra (eds). Bryophytes of the Polish Carpathians. Sorus, Poznań: 185-200. 
Сүкошsка В. (2011): Bryophytes of Sphagnum-Polytrichum hummocks in the Polish Tatra Mountains. In: A. Stebel, R. Ochyra (eds). Bryophytes of the Polish Carpathians. Sorus, Poznań: 233-259.

Dierssen K. (2001): Distribution, ecological amplitude and phytosociological characterization of European bryophytes. Bryophytorum Bibliotheca 56: 3-289.

Drehwald U., Preising E. (1991): Die Pflanzengesellschaften Niedersachsens. Bestandsentwicklung, Gefährdung und Schutzprobleme. Moosgesellschaften. In: Naturschutz und Landschaftspflege in Niedersachsen 20/9. Hannover.

DuDA J., VÁŇA J. (1990): Rozšíření játrovek v Československu. LIX. Časopis Slezského Muzea Opava, Series A, 39: 193-205.

Düll R., Meinunger L. (1989): Deutschland Moose. Die Verbreitung der deutschen Moose in der BR Deutschland und in der DDR, ihre Höhenverbreitung, ihre Arealtypen, sowie Angaben zum Rückgang der Arten. 1 Teil. IDH Verlag, Bad Münstereifel, Ohlerath.

Ellis L.T., Alegro A., Bednarek-Ochyra H., Ochyra R., Bergamini A., Cogoni A., Erzberger P., Górski P., Gremmen N., Hespanhol H., Vieira C., Kurbatova L.E., Lebouvier M., Martinčič A., Asthana A.K., Gupta R., Nath V., Natcheva R., Ganeva A., Özdemir T., Batan N., Plášek V., Porley R.D., Randič M., Sawicki J., Schroder W., Sérgio C., Smith V.R., Sollman P., Ştefănuț S., Stevenson C.R., SuÁrez G.M., Surina B., Uyar G., Modrič Surina Z. (2012): New national and regional bryophyte records 31. Journal of Bryology 34(2): 123-124.

Fојсік B. (2015): 14. Orthodontium lineare Schwägr. In: P. Górski, A. Rusińska (eds). New distributional data on bryophytes of Poland and Slovakia, 3. Steciana 19(3): 167.

Fojcik B., Stebel A. (2006): Chosen aspects of threatened moss species occurrence in urban areas - a case study of Katowice. Biodiversity: Research and Conservation 1-2: 187-189.

FudAli E. (1993): Current distribution of Orthodontium lineare (Musci, Bryaceae) in Poland. Fragmenta Floristica et Geobotanica 38(1): 159-162.

Fudali E., SzCZEPańSKi M., RusińsKa H., RosadzińsKi S., Wolski G. (2009): The current distribution in Poland of some European neophytic bryophytes with supposed invasive tendencies. Acta Societatis Botanicorum Poloniae 78(1): 73-80.

GoŁdyn R., GoŁdyn H., Kaniewski W. (2007): Zbiorowiska roślinności szuwarowej doliny Cybiny (Centralna Wielkopolska). Cz. 2. Badania Fizjograficzne nad Polską Zachodnią, Seria B, Botanika 56: 91-110.

GóRSKI P. (2013): Wątrobowce (Marchantiophyta) Leśnego Kompleksu Promocyjnego "Lasy Środkowopomorskie" (Pomorze Zachodnie). PGL Lasy Państwowe Nadleśnictwo Karnieszewice, Wy- dawnictwo Uniwersytetu Przyrodniczego w Poznaniu, Sianów-Poznań.

GóRsKI P. (2014): 9. Fuscocephaloziopsis loitlesbergeri (Schiffn.) Váňa et L. Söderstr. In: P. Górski, A. Stebel, A. Rusińska (eds). New distributional data on bryophytes of Poland, 1. Steciana 18(2): 79.

GóRSKI P. (2015): 14. Odontoschisma fluitans (Nees) L. Söderstr. et Váňa (=Cladopodiella fluitans (Nees) H. Buch). In: P. Górski, A. Rusińska (eds). New distributional data on bryophytes of Poland, 4. Steciana 19(4): 225.

GóRski P., GĄBKA M. (2015): 4. Cephaloziella elachista (J.B. Jack ex Gottsche et Rabenh.) Schiffn. In: P. Górski, A. Rusińska (eds). New distributional data on bryophytes of Poland, 2. Steciana 19(2): 57.

GÓRSKI P., KAPUSTYŃSKI T. (2015): 11. Kurzia pauciflora (Dicks.) Grolle. In: P. Górski, A. Rusińska (eds). New distributional data on bryophytes of Poland, 4. Steciana 19(4): 224-225.

GóRski P., KapustyŃski T., Smoczyk M. (2015): 3. Cephaloziella elachista (J.B. Jack ex Gottsche et Rabenh.) Schiffn. In: P. Górski, A. Rusińska (eds). New distributional data on bryophytes of Poland, 4. Steciana 19(4): 222.

GóRSKI P., VÁÑa J. (2014): A synopsis of liverworts occurring in the Tatra Mountains (Western Carpathians, Poland and Slovakia): checklist, distribution and new data. Preslia 86(4): 381-485.

Gos L., Gos K. (1993): New records of Orthodontium lineare (Musci, Bryaceae) in northern Poland. Fragmenta Floristica et Geobotanica 38(1): 324-327.

HÜBsCHMANN A. (1986): Prodromus der Moosgesellschaften Zentraleuropas. Bryophytorum Bibliotheca 32: 1-413.

JANicKA M. (2012): Brioflora ostańców wapiennych w otulinie Ojcowskiego Parku Narodowego (Wyżyna Krakowska). Fragmenta Floristica et Geobotanica Polonica 19(1): 117-123.

JeNík J. (1958): Rašelinowé kopceky v oblasti Velkej Kopy (2053 m) vo Vysokých Tatrách. Sbornik Prác o Tatranskom Národnom Parku 2: 30-40.

Klama H. (1996): Wątrobowce (Hepaticae) Beskidu Żywiecko-Orawskiego (Karpaty Zachodnie). Monographiae Botanicae 79: 1-144.

KLAMA H. (2006): Red list of the liverworts and hornworts in Poland - Czerwona lista wątrobowców i glewików w Polsce. In: Z. Mirek, K. Zarzycki, W. Wojewoda, Z. Szeląg (eds). Red list of plants and fungi in Poland - Czerwona lista roślin i grzybów Polski. W. Szafer Institute of Botany, Polish Academy of Sciences, Kraków: 21-33.

Klama H. (2013): Materiały do flory wątrobowców masywu Babiej Góry (Karpaty Zachodnie). Fragmenta Floristica et Geobotanica Polonica 20(1): 93-108.

KLAMA H., GóRski P., URbaŃSKi P. (2005): Liverworts of the "Dębowiec" nature reserve (Central Poland). 
Roczniki Akademii Rolniczej w Poznaniu 373, Botanika-Steciana 9: 111-119.

Klama H., ŻARnOwieC J. (2011): Mszaki zespołu przyrodniczo-krajoznawczego "Gościnna Dolina" w Bielsku-Białej (Pogórze Śląskie, południowa Polska). Nauka Przyroda Technologie 5, 4\#70.

KoŁA W. (1967): Materiały do flory wątrobowców Gór Bystrzyckich. Acta Universitatis Wratislaviensis 62, Prace Botaniczne 8: 85-98.

Koppe F., Koppe K. (1931): Zur Moosflora Ostpreussens. Unser Ostland 1(6): 299-394.

Koppe F., Koppe K. (1937): Zur Moosflora Ostpreussens. 2. Schriften der Physikalisch-Ökonomischen Gesellschaft (Königsberg) 69: 357-382.

KRUPA J. (1888): Zapiski bryjologiczne z Tatr i Przedtatrza. Sprawozdanie Komisyi Fizyograficznej, Akademia Umiejętności w Krakowie 21: 65-94.

KuCHARSKI L., KurZAC M. (1998): Nowe stanowiska rzadkich i interesujących gatunków roślin na obszarze Parku Krajobrazowego Międzyrzecza Warty i Widawki i terenach przyległych. Acta Universitatis Lodziensis, Folia Botanica 12: 109-113.

LiLIENFELdówna F. (1914): Przyczynek do znajomości krajowych wątrobowców. Sprawozdanie Komisyi Fizyograficznej, Akademia Umiejętności w Krakowie 48: 59-63.

Limpricht K.G. (1876): Nachträge zu den Laub- und Lebermoose. In: F. Cohn (ed.). KryptogammenFlora von Schlesien. Band 1. J.U. Kern's Verlag, Breslau: 413-444.

MAMiŃSKi M. (1986): Zbiorowiska roślinne torfowisk Bełchatowskiego Okręgu Przemysłowego. Acta Universitatis Lodziensis, Folia Botanica 4: 85-137.

Marstaller R. (2006): Syntaxonomischer Konspekt der Moosgesellschaften Europas und angrenzender Gebiete. Haussknechtia, Beiheft 13: 1-192.

MeINUNGER L., SCHRÖDER W. (2007): Verbreitungsatlas der Moose Deutschlands. Band 3. Eigenverlag der Regensburgischen Botanischen Gesellschaft von 1790 e. V., Regensburg.

MierzeńsKa M. (1994): Wątrobowce Gorców. Fragmenta Floristica et Geobotanica, Series Polonica 1: 235-346.

Nejfeld P., Stebel A. (2007): Szata roślinna wapiennych wzniesień Matyska i Kopa (Kotlina Żywiecka, Karpaty Zachodnie) oraz propozycje jej ochrony. Część 1 . Flora roślin naczyniowych i mszaków. Natura Silesiae Superioris 10: 19-36.

OchYra R. (1982): Orthodontium lineare Schwaegr. a new species and genus in the moss flora of Poland. Bryologische Beiträge 1: 23-36.

Ochyra R., CYкоWsKa B. (2008): The liverwort flora of the Skalice Nowotarskie and Spiskie Klippen (Polish Western Carpathians). In: A. Stebel, R. Ochyra (eds). Bryophytes of the Polish Carpathians. Sorus, Poznań: 143-167.
Ochyra R., Szmajda P., Bednarek H., Bocheński W. (1988): M. 524. Scorpidium scorpioides (Hedw.) Limpr. In: Z. Tobolewski, T. Wojterski (eds). Atlas of the geographical distribution of spore plants in Poland. Vol. 3. Series 5. Mosses (Musci). W. Szafer Institute of Botany of the Polish Academy of Science, Państwowe Wydawnictwo Naukowe, Warszawa-Poznań: 41-47.

Pisarek W. (1989): Flora polan Puszczy Bolimowskiej i jej aspekt sozologiczny. Fragmenta Floristica et Geobotanica 34(1-2): 81-100.

Piwowarski B., Paciorek T. (2012): Materiały do brioflory rezerwatu przyrody „Góra Miedzianka” w Górach Świętokrzyskich. Naturalia 1: 96-102.

Plackowski R. (1984): Ginące torfowisko w okolicy Bełchatowa. Chrońmy Przyrodę Ojczystą 40(2): 32-33.

PLÁšEK V. (2012): Klíč pro determinaci zástupců rodů Orthotrichum a Nyholmiella v České republice. Bryonora 50: 17-33.

PlášeK V., KuČera J., Musil Z., Číhal L., ŠTeChová T. (2012): Mechorosty zaznamenané v průběhu 19. jarního bryologicko-lichenologického setkání v Orlických horách. Bryonora 50: 34-39.

Plášek V., Stebel A. (2002): Bryophytes of the Čantoryjský hřbet range (Czantoria range) and its foothills (Western Carpathians - Czech Republic, Poland). Časopis Slezského Zemského Muzea Opava (A) 51: 1-87.

Rakowski W. (2001): Wrzosowiska Puszczy Noteckiej. In: M. Wojterska (ed.). Szata roślinna Wielkopolski i Pojezierza Południowopomorskiego. Przewodnik sesji terenowych 52. zjazdu Polskiego Towarzystwa Botanicznego, 24-28 września 2001. Bogucki Wydawnictwo Naukowe, Poznań: 220-227.

RaKowski W. (2003): Zbiorowiska wrzosowisk z rzę$\mathrm{du}$ Vaccinio myrtilli-Genistetalia pilosae Schubert 1960 ex Passarge 1964 w Wielkopolsce. Cz. 1. Scabioso canescentis-Genistetum tinctoriae Balcerkiewicz et Brzeg 1993 ex Brzeg et M. Wojterska 2001. Badania Fizjograficzne nad Polską Zachodnią, Seria B, Botanika 52: 27-64.

RAKowsKi W. (2009): Zbiorowiska wrzosowisk z rzę$\mathrm{du}$ Vaccinio myrtilli-Genistetalia pilosae Schubert 1960 ex Passarge 1964 w Wielkopolsce. Cz. 2. Arctostaphyllo-Callunetum (Juraszek 1928) R. Tx. et Preising 1940 ex Faliński 1965. Badania Fizjograficzne nad Polską Zachodnią, Seria B, Botanika 58: 19-51.

ReINChARDt O. (1863): Übersicht der in der Mark Brandenburg bisher beobachteten Laubmoose. Verhandlungen des Botanischen Vereins für die Provinz Brandenburg und die angrenzenden Länder 5: 1-52.

Reiter K. (1920): Die Bedeutung der Seefelder bei Reinerz für Pflanzenforschung und Naturdenkmalpflege. In: E. Hermann, K. Reiter, H. Lütt- 
schwager. Die Seefelder bei Reinerz. Beiträge zur Naturdenkmalpflege 6(2), Berlin: 145-226.

Rejment I. (1936): Przyczynek do znajomości flory wątrobowców (Hepaticae) Pogórza Cieszyńskiego. In: Biocenoza lasów Pogórza Cieszyńskiego. Polska Akademia Umiejętności, Wydawnictwa Śląskie, Prace biologiczne 1: 113-130.

Rejment-Grochowska I. (1950): Czynniki ekologiczne i rozmieszczenie geograficzne wątrobowców (Hepaticae) Beskidu Śląskiego. Prace Biologiczne Śląskie 2: 3-71.

RosADZiŃSKI S. (2013): Moss flora of Lower Lusatia: species richness, geographical elements and peculiarities. In: A. Biedunkiewicz, M. Dynowska (eds). Interdyscyplinarne i aplikacyjne znaczenie nauk botanicznych. Streszczenia wystąpień ustnych i plakatów 56. Zjazd Polskiego Towarzystwa Botanicznego Olsztyn, 24-30 czerwca 2013. Mantis, Olsztyn: 430.

RusiŃsKA A. (1981): Mchy Pojezierza Kartuskiego. Prace Komisji Biologicznej Poznańskiego Towarzystwa Przyjaciół Nauk 59: 1-155.

RusińsKa A., Górski P., Stebel A., Rosadziński S., StaNiAsZeK-KiK M., Wilhelm M., Wolski G.J., Fudali E., Gos K., Gos L. (2010): Mszaki źródlisk wapiennych koło Drzewian na Wysoczyźnie Polanowskiej. In: W. Gil (ed.) Różnorodność biologiczna Leśnego Kompleksu Promocyjnego Lasy Warcińsko-Polanowskie, Zeszyt 2. Nadleśnictwo Polanów, Polanów: 7-14.

RusińSKA A., Urbański P. (1993): Nowe stanowiska Orthodontium lineare Schwaegr. i Campylopus introflexus (Hedw.) Brid. na Pomorzu Zachodnim. Badania Fizjograficzne nad Polską Zachodnią, Seria B, Botanika 42: 225-227.

Sanderska A., Filipiak E., Pisarek W. (2003): Bryophytes in the Bolimów Landscape Park. Monographiae Botanicae 92: 197-231.

SCHÄFER-VERWIMP A. (2001): Orthotrichum Hedw., Goldhaarmoos. In: M. Nebel, G. Philippi (eds). Die Moose Baden-Württembergs, Band 2: Spezieller Teil (Bryophytina II, Schistostegales bis Hypnobryales). Ulmer, Stuttgart: 170-197.

Schumacker R., Martiny Ph. (1995): Threatened bryophytes in Europe including Macaronesia. In: European Commitee for Conservation of Bryophytes, Red Data Book of European Bryophytes. ECCB, Trondheim: 29-194.

SöDERSTRÖM L., Urmi E., VÁŇA J. (2002): Distribution of Hepaticae and Anthocerotae in Europe and Macaronesia. Lindbergia 27: 3-47.

StANIASZEK-KIK M., WolsKI G.J. (2009): Mszaki - zróżnicowanie, zmiany i zagrożenia. In: J.K. Kurowski (ed.). Szata roślinna Polski środkowej. Towarzystwo Ochrony Krajobrazu, Wydawnictwo EKO-GRAF, Łódź: 48-56.

Stebel A. (2013): Synanthropization of the bryoflora of Poland. In: A. Biedunkiewicz, M. Dynowska (eds). Interdyscyplinarne i aplikacyjne znaczenie nauk botanicznych. Streszczenia wystąpień ustnych i plakatów. 56. Zjazd Polskiego Towarzystwa Botanicznego Olsztyn, 24-30 czerwca 2013. Mantis, Olsztyn: 159-160.

Stebel A., Klama H., Wierzcholska S., Plášek V. (2003): Porella platyphylla (L.) Pfeiff. (Hepaticophy$t a$, Porellaceae) in the Białowieża Primeval Forest (Poland). Časopis Slezského Zemského Muzea Opava (A) 52: 270-272.

Stebel A., Koczur A. (2012): Materiały do flory mchów torfowisk i młak Bieszczadów Zachodnich (Polskie Karpaty Wschodnie). Roczniki Bieszczadzkie 20: 98-115.

Stebel A., Rosadziński S., Górski P., Fojcik B., Rusińska A., Vončina G., Szczepański M., Wilhelm M., Fudali E., Paciorek T., Staniaszek-Kik M., Zubel R., Piwowarski B., Wolski G.J., Salachna A., SmolińSKA D., PierścińsKa A. (2013): Contribution to the bryoflora of the Świętokrzyski National Park (Central Poland). Roczniki Akademii Rolniczej w Poznaniu 392, Botanika-Steciana 17: 77-84.

Stebel A., Wilczek Z. (2000): Szata roślinna rezerwatu przyrody „Grapa” w Kotlinie Żywieckiej (Karpaty Zachodnie). Ochrona Przyrody 57: 59-71.

SzWEYKowski J. (1953): Mszaki Gór Stołowych. Cz. 1. Wątrobowce (Hepaticae). Prace Komisji Biologicznej Poznańskiego Towarzystwa Przyjaciół Nauk 14(5): 1-134.

SzWEYKOWSKI J. (1956): Materiały do geografii wątrobowców polskich I. Rozmieszczenie wątrobowca Barbilophozia kunzeana (Hüb.) K. M. w Polsce. Acta Societatis Botanicorum Poloniae 25: 589-602.

SzWeykowski J. (1958): Prodromus florae hepaticarum Poloniae. Prace Komisji Biologicznej Poznańskiego Towarzystwa Przyjaciół Nauk 19: 1-600.

SzWEYKowsKi J. (1960a): Materiały do flory wątrobowców Tatr. Prace Komisji Biologicznej Poznańskiego Towarzystwa Przyjaciół Nauk 21 (3): 3-92.

SzWEYKOWsKi J. (1960b): Orthocaulis binsteadii (Kaalaas) Buch - a new liverwort for Central Europe. Fragmenta Floristica et Geobotanica 6(3): 399405.

SZWEYKOWSKi J. (1966): H. 65. Trichocolea tomentella (Ehrh.) Dum. In: Z. Czubiński, J. Szweykowski (eds). Atlas of the geographical distribution of spore plants in Poland. Series 4. Wątrobowce - Liverworts (Hepaticae). Vol. 3. Komitet Botaniczny Polskiej Akademii Nauk, Poznańskie Towarzystwo Przyjaciół Nauk, Wydział Matematyczno-Przyrodniczy, Komisja Biologiczna, Poznań: 25-26.

SzWEYKOWSKI J. (2006): An annotated checklist of Polish liverworts and hornworts. - Krytyczna lista wątrobowców i glewików Polski. Biodiversity of Poland. Vol. 4. W. Szafer Institute of Botany, Polish Academy of Sciences, Kraków.

SzWEYKOWSKI J., BuczKowsKa K. (2000): Sphagnum-Polytrichum hummocks: a bryologically ne- 
glected plant formation. Fragmenta Floristica Geobotanica 45: 475-484.

SzWEYKOWSKI J., KoźLICKA M. (1966): Wątrobowce wyspy Wolina i południowo-wschodniego Uznamu. Badania Fizjograficzne nad Polską Zachodnią 18: 155-178.

SzWEYKOWSKi J., KoźLICKA M. (1969): Materiały do flory wątrobowców Pomorza. Badania Fizjograficzne nad Polską Zachodnią 23: 125-149.

TORKA V. (1904): Moose des Kreises ZüllichauSchwiebus. Helios. Abhandlungen und Mitteilungen aus dem Gesamtgebiete der Naturwissenschaften. Organ des Naturwissenschaftlichen Vereins des Regierungsbezirkes Frankfurt 21: 51-86.

URBAŃSKI P. (1987): Orthodontium lineare Schwaegr. na Pomorzu Zachodnim. Badania Fizjograficzne nad Polską Zachodnią, Seria B, Botanika 38: 177-180.

Warnstorf C. (1885): Moosflora der Provinz Brandenburg. Eine systematische zusammenstellung der bisher in diesem Gebiete beobachteten Leber-, Torf- und Laubmoose. Verhandlungen des botanischen Vereins der Provinz Brandenburg 27: $1-94$.

WilHeLm M. (2015): 4. Campylopus pyriformis (Schultz) Brid. In: P. Górski, A. Rusińska (eds). New distributional data on bryophytes of Poland and Slovakia, 3. Steciana 19(3): 164.

Woziwoda B., Staniaszek-Kik M. (2012): Diversity of bryophytes in plant communities created under impact of anthropogenic disturbance in the Ługi peatland area. In: J. Forysiak, L. Kucharski, M. Ziułkiewicz (eds). Peatlands in semi-natural landscape - their transformation and the possibility of protection. Bogucki Wydawnictwo Naukowe, Poznań: 41-47.

Żarnowiec J., Stebel A., Ochyra R. (2004): Threatened moss species in the Polish Carpathians in the light of a new Red list of mosses in Poland. In: A. Stebel, R. Ochyra (eds). Bryological studies in the Western Carpathians. Sorus, Poznań: 9-28.

Zubel R. (2002): Siedliskowe uwarunkowania występowania i rozmieszczenie wątrobowców $\mathrm{w}$ dolinie Potoku Olchowskiego (Góry Słonne, Bieszczady Niskie). Fragmenta Floristica et Geobotanica Polonica 9: 329-344.

For citation (1): GóRsKi P., SMOCZYK M., RosadziŃski S., Staniaszek-Kik M., Klama H., Pawlikowski P., Wilhelm M., TopolsKa K., Romański M. (2016): New distributional data on bryophytes of Poland and Slovakia, 7. Steciana 20(3): 117-127. doi: 10.12657/steciana. 020.014

For citation (2): SмосZук M. (2016): 9. Orthotrichum cupulatum Hoffm. ex Brid. In: P. Górski, A. Rusińska (eds). New distributional data on bryophytes of Poland and Slovakia, 7. Steciana 20(3): 121. doi: 10.12657/steciana.020.014 